Article

\title{
Changing Low Flow and Streamflow Drought Seasonality in Central European Headwaters
}

\author{
Vojtech Vlach ${ }^{1, *} \mathbb{C}$, Ondrej Ledvinka ${ }^{2}(\mathbb{D})$ and Milada Matouskova ${ }^{1}$ \\ 1 Department of Physical Geography and Geoecology, Faculty of Science, Charles University, Albertov 6, \\ 12843 Prague 2, Czech Republic; milada.matouskova@natur.cuni.cz \\ 2 Czech Hydrometeorological Institute, Hydrology Database and Water Budget Department, \\ Na Sabatce 2050/17, 14306 Prague 412, Czech Republic; ondrej.ledvinka@chmi.cz \\ * Correspondence: vlachv@natur.cuni.cz; Tel.: +420-607-570-944
}

Received: 11 November 2020; Accepted: 18 December 2020; Published: 20 December 2020

\begin{abstract}
In the context of the ongoing climate warming in Europe, the seasonality and magnitudes of low flows and streamflow droughts are expected to change in the future. Increasing temperature and evaporation rates, stagnating precipitation amounts and decreasing snow cover will probably further intensify the summer streamflow deficits. This study analyzed the long-term variability and seasonality of low flows and streamflow droughts in fifteen headwater catchments of three regions within Central Europe. To quantify the changes in the low flow regime of selected catchments during the 1968-2019 period, we applied the R package lfstat for computing the seasonality ratio (SR), the seasonality index (SI), mean annual minima, as well as for the detection of streamflow drought events along with deficit volumes. Trend analysis of summer minimum discharges was performed using the Mann-Kendall test. Our results showed a substantial increase in the proportion of summer low flows during the analyzed period, accompanied with an apparent shift in the average date of low flow occurrence towards the start of the year. The most pronounced seasonality shifts were found predominantly in catchments with the mean altitude 800-1000 m.a.s.l. in all study regions. In contrast, the regime of low flows in catchments with terrain above 1000 m.a.s.l. remained nearly stable throughout the 1968-2019 period. Moreover, the analysis of mean summer minimum discharges indicated a much-diversified pattern in behavior of long-term trends than it might have been expected. The findings of this study may help identify the potentially most vulnerable near-natural headwater catchments facing worsening summer water scarcity.
\end{abstract}

Keywords: low flows; streamflow drought; minimum discharges; headwater; seasonality; trends

\section{Introduction}

Regional and local hydrological studies are of high importance because they present both spatial and temporal variability of runoff characteristics, although on a relatively small scale [1,2]. The assessment of the streamflow extremes on a local scale should begin with the identification of typical seasonal variations occurring over time [3]. Due to the changing climate, these patterns may be either aggravating or weakening throughout a longer period of time [4,5].

The increasing frequency, intensity and duration of streamflow droughts in mid-latitudes of the Northern Hemisphere represent some of the predicted effects of climate change [6-8]. In the context of increasing severity of droughts in Europe during the last decade [9-11], the effects of climate change on runoff regime will very likely affect the runoff seasonality, variability of discharge and also the risk of extreme streamflow drought occurrence [12,13]. Under conditions of rising air temperature, increasing evaporation rates, decreasing soil-moisture [14-16] and decreasing snow cover in the Central European region [17-19], the droughts are more likely to occur and escalate into multiyear events. 
The evidence suggests that severe droughts may cause particularly dangerous impacts for society, agriculture, ecosystems and water management if the events last more than one year and water resources cannot be completely recharged [20-23]. During such periods, the increased water demand could further intensify streamflow droughts, affecting negatively either low flows or deficit volumes [24]. Recent observations from Europe showed that many regions with a flow regime driven by rainfall, such as southern France, southwestern England or Central Europe will be prone to multiyear drought in the future [25]. In contrast, the catchments with a flow regime dominated by snowmelt should not be significantly affected by multiyear drought events, indicating an increasing divergence in the probability of drought occurrence across Europe $[25,26]$. However, there are also predictions of a significant decrease in summer low flows due to a shift in snowmelt season and overall decrease in snow water equivalent even for elevations around 1000 m.a.s.l. and higher [27].

The effect of climate change on low flows and their seasonality has also been a subject of recent European studies [28-30]. In many catchments of different scales in Central Europe, e.g., the Upper Rhine, the future shift from the winter low-flow regime to the summer low-flow regime is expected. Furthermore, the variability of low-flow event timing will also decrease with ongoing climate warming, which should make the droughts more predictable [31]. To understand the long-term behavior of the runoff changes in Central Europe, the observations from near-natural catchments are highly important [32]. The observed patterns from Central European headwaters might therefore provide valuable information for research in other regions.

The main aim of this study was to evaluate the long-term variability and seasonality of low flows and streamflow droughts in 15 headwater, near-natural catchments of five mountain ranges and highlands within the Central European region. With respect to the outputs of recent studies with similar interest reflecting consecutive warming, decreasing snow cover and relatively stable amounts of total precipitation in the Central European region [12,18,33,34], we hypothesized that (1) the ongoing climate change causes a significant change in the ratio between summer and winter low flows, which (2) affects the seasonal distribution of low flows and streamflow droughts in the study catchments, and that (3) the duration and magnitude of streamflow drought events are therefore increasing during the analyzed period.

To perform the analysis of low flow and streamflow drought characteristics in study catchments, we used a set of daily discharge data for the 1968-2019 period. The seasonality ratio (SR) was used to characterize the low-flow regime of the rivers, the seasonality index (SI) was derived to evaluate the average timing and concentration of low flows and streamflow droughts during the year. For each catchment, the durations of streamflow drought events along with the deficit volumes were derived. The Mann-Kendall nonparametric test together with Sen's slope estimator were used to examine the significance and direction of trends in time series of seven- and 30-day mean summer minimum discharges (MSM-7; MSM-30).

To provide a detailed insight into the dynamics and evolution of low-flow and streamflow drought indices and characteristics in the study catchments during the evaluated period (1968-2019), we derived the 30-year moving averages for most of the low-flow and drought indices as well as for their trend properties. This approach allowed us to observe the recent variations and inner changes of the low-flow regime in selected Central European headwaters more closely and it also diminished the influence of short-term variations and outliers within the observation period. This research helps to explore the potentially most vulnerable, near-natural headwater catchments to the summer water scarcity in Central Europe.

\section{Materials and Methods}

\subsection{Study Area}

This study was performed in 15 headwater catchments in mountains and highlands along the Czech Republic's border with Germany and Poland (Figure 1). Geographically, the study catchments 
were divided into three groups according to their location in order to better distinguish the intraand inter-regional variability of the results according to their physiographic properties (Table 1). The regions were specified as follows:

- $\quad$ Southwest (SW): catchments of the Bohemian Forest (BLA, KOL, MOD) and the Bavarian Forest (HOL, LOH, LIN)

- $\quad$ Northwest (NW): catchments of the Ore Mountains (KLI, CHA, ROT, REH and AMM)

- $\quad$ Northeast (NE): catchments of the Giant Mountains (JAN, DOL, HOR) and the Broumov Highlands (MAR)

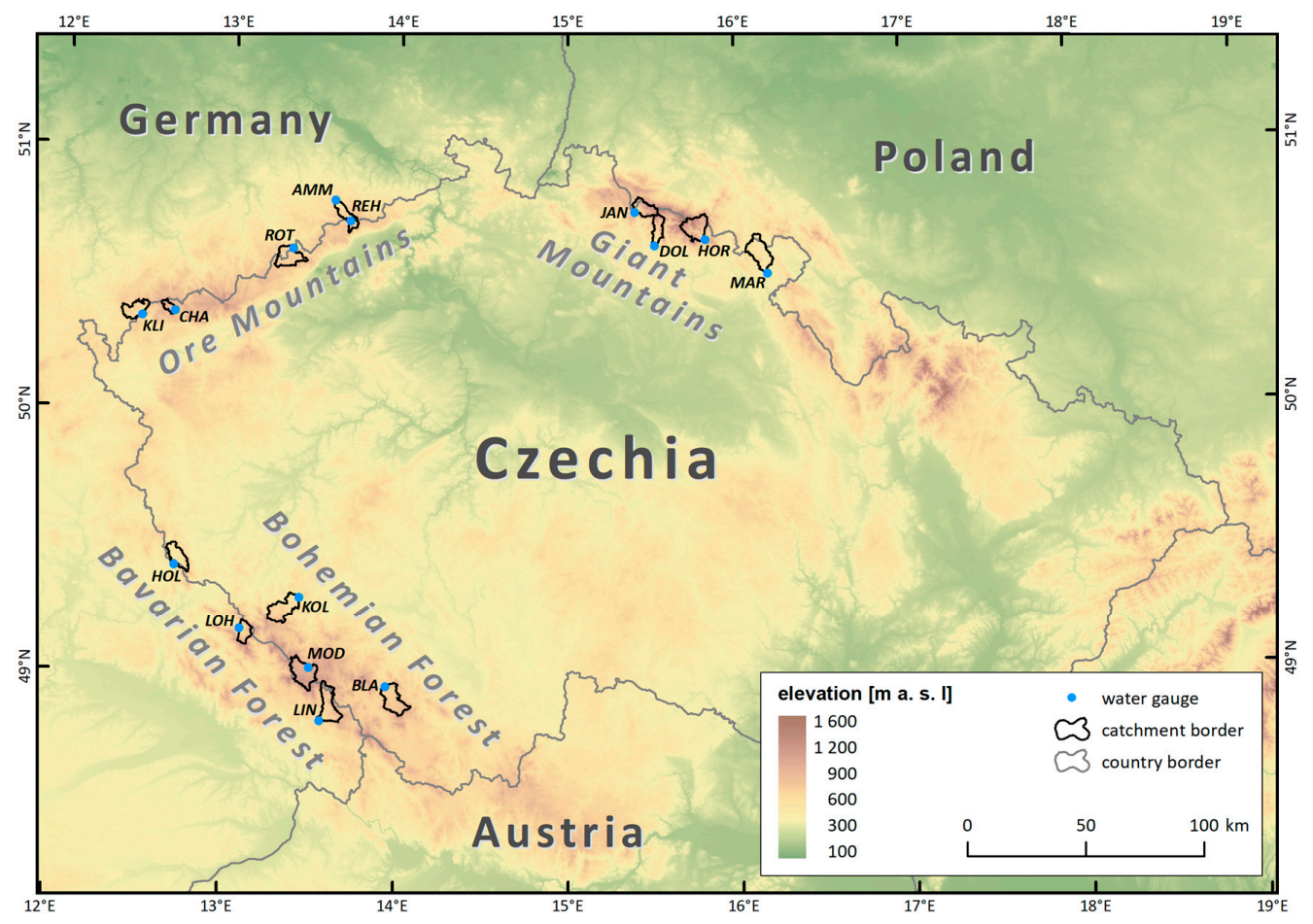

Figure 1. Study catchments and their river gauging stations. Data: CHMI, GKD Bayern and LfULG.

Twelve of the selected catchments belong to the Elbe River basin, while the remaining three catchments in the SW region (HOL, LOH and LIN) represent headwaters of the Danube tributaries. Generally, the study catchments were selected because of multiple necessary conditions:

- Availability of at least 50 years of daily streamflow time series;

- Absence of dams, large weirs or other structures significantly regulating streamflow;

- Areal and altitudinal properties (area $<100 \mathrm{~km}^{2}$, mean altitude $>550$ m.a.s.l.).

Although the catchments were chosen based on criteria of similarity, there are some variations in their physical and natural properties worth noting. According to the Köppen-Geiger climate classification, catchments with mean altitude above 850 m.a.s.l. belong to the Dfb category, while study catchments with lower average altitude are classified as $\mathrm{Cfb}$ [35]. Study catchments receive a relatively evenly distributed amount of annual precipitation that ranges from 800 to $1300 \mathrm{~mm}$. Annual mean air temperatures vary between 2.5 and $8{ }^{\circ} \mathrm{C}$, with respect to the altitude. All study catchments are located in mountains and highlands of the Bohemian Massif, which is the Central European part of the Hercynian system. Fourteen of the study catchments are predominantly based on crystalline bedrock, whereas the only MAR catchment is based on Mesozoic sedimentary sandstones [36]. 
Table 1. Basic characteristics of study catchments. Data: CHMI, GKD Bayern, LfULG Sachsen.

\begin{tabular}{|c|c|c|c|c|c|c|c|c|c|}
\hline Stream Gauge & Abbrev. & Stream & Region & Area $\left(\mathrm{km}^{2}\right)$ & $\begin{array}{c}\text { Stream } \\
\text { Gauge } \\
\text { Coordinates }\end{array}$ & $\begin{array}{c}\text { Gauge } \\
\text { Elevation } \\
\text { (m.a.s.1.) }\end{array}$ & $\begin{array}{c}\text { Mean } \\
\text { Elevation } \\
\text { (m.a.s.1.) }\end{array}$ & Mean Slope $\left({ }^{\circ}\right)$ & $\begin{array}{c}\text { Dominant } \\
\text { Hillslope } \\
\text { Orientation }\end{array}$ \\
\hline Blanicky Mlyn & BLA & Blanice & SW & 85.47 & $\begin{array}{l}48.957 \mathrm{~N} \\
13.941 \mathrm{E}\end{array}$ & 743.42 & 897.1 & 5.72 & $\mathrm{~N} ; \mathrm{NW}$ \\
\hline Kolinec & KOL & Ostruzna & SW & 91.68 & $\begin{array}{l}49.296 \mathrm{~N} \\
13.436 \mathrm{E}\end{array}$ & 531.65 & 755.7 & 7.33 & $\mathrm{NE} ; \mathrm{N}$ \\
\hline Modrava & MOD & Vydra & SW & 89.80 & $\begin{array}{l}49.026 \mathrm{~N} \\
13.497 \mathrm{E}\end{array}$ & 973.28 & 1146.6 & 5.42 & $\mathrm{NE} ; \mathrm{W}$ \\
\hline Höll & HOL & Schwarzach & SW & 59.90 & $\begin{array}{l}49.410 \mathrm{~N} \\
12.704 \mathrm{E}\end{array}$ & 493.25 & 651.7 & 7.93 & SW; W \\
\hline Linden & LIN & Sausswasser & SW & 89.70 & $\begin{array}{l}48.825 \mathrm{~N} \\
13.565 \mathrm{E}\end{array}$ & 649.74 & 899.2 & 7.81 & SW; W \\
\hline Lohberg & $\mathrm{LOH}$ & Weißer Regen & SW & 39.30 & $\begin{array}{l}49.172 \mathrm{~N} \\
13.091 \mathrm{E}\end{array}$ & 575.76 & 927.5 & 13.27 & SW; W \\
\hline Klingenthal 1 & KLI & Zwota & NW & 55.70 & $\begin{array}{l}50.354 \mathrm{~N} \\
12.471 \mathrm{E}\end{array}$ & 540.10 & 719.7 & 8.89 & $\mathrm{SE} ; \mathrm{S}$ \\
\hline Chaloupky & $\mathrm{CHA}$ & Rolava & NW & 20.06 & $\begin{array}{l}50.374 \mathrm{~N} \\
12.664 \mathrm{E}\end{array}$ & 804.62 & 907.1 & 3.95 & $\mathrm{~S} ; \mathrm{SW}$ \\
\hline Rothenthal & ROT & Natzschung & NW & 76.10 & $\begin{array}{l}50.619 \mathrm{~N} \\
13.360 \mathrm{E}\end{array}$ & 538.22 & 762.8 & 5.10 & $\mathrm{NE} ; \mathrm{N}$ \\
\hline Rehefeld 2 & REH & $\begin{array}{c}\text { Wilde } \\
\text { Weißeritz }\end{array}$ & NW & 15.40 & $\begin{array}{l}50.728 \mathrm{~N} \\
13.701 \mathrm{E}\end{array}$ & 685.45 & 805.6 & 5.93 & W; NW \\
\hline Ammelsdorf & AMM & $\begin{array}{c}\text { Wilde } \\
\text { Weißeritz }\end{array}$ & NW & 49.30 & $\begin{array}{l}50.805 \mathrm{~N} \\
13.607 \mathrm{E}\end{array}$ & 527.37 & 734.4 & 7.12 & $\mathrm{NE} ; \mathrm{W}$ \\
\hline Janov-Harrachov & JAN & Mumlava & $\mathrm{NE}$ & 51.31 & $\begin{array}{l}50.765 \mathrm{~N} \\
15.397 \mathrm{E}\end{array}$ & 580.65 & 978.7 & 11.08 & SW; W \\
\hline Dolni Stepanice & DOL & Jizerka & $\mathrm{NE}$ & 44.08 & $\begin{array}{l}50.638 \mathrm{~N} \\
15.517 \mathrm{E}\end{array}$ & 441.51 & 860.3 & 13.88 & SW; S \\
\hline Horni Marsov & HOR & Upa & $\mathrm{NE}$ & 81.99 & $\begin{array}{l}50.661 \mathrm{~N} \\
15.820 \mathrm{E}\end{array}$ & 570.45 & 1048.4 & 16.01 & $\mathrm{SE} ; \mathrm{E}$ \\
\hline Marsov n. Metuji & MAR & Metuje & $\mathrm{NE}$ & 94.68 & $\begin{array}{l}50.530 \mathrm{~N} \\
16.190 \mathrm{E}\end{array}$ & 418.03 & 583.7 & 8.07 & $\mathrm{E} ; \mathrm{SE}$ \\
\hline
\end{tabular}




\subsection{Data and Materials}

Time series of mean daily discharge data were obtained from local hydrological services. The Czech Hydrometeorological Institute (CHMI) provided streamflow data for water gauges BLA, KOL, MOD, CHA, JAN, DOL, HOR and MAR, the Bavarian Environmental Agency (GKD Bayern) provided data for gauges HOL, LIN and LOH, and the Saxon State Office for the Environment, Agriculture and Geology (LfULG Sachsen) provided data for stations KLI, ROT, REH and AMM [37-39]. The time series span analyzed in this study for all 15 water gauges was set to years 1968-2019, which is the longest time period available for all catchments.

Not all time series used in this study were entirely complete. In the KLI series, the water year 1970 was missing, as well as the period between January and May 2003 in the AMM series. Several attempts using various methods were made to fill in missing data, such as Kalman filtering [40], singular spectrum analysis [41] or seasonally decomposed imputation [42]. For the imputation of the missing values, these methods apply solely the properties of the time series itself (e.g., structural models). However, none of the results were satisfactory enough. Although the filled values corresponded well with the average annual seasonality of daily discharges, the endpoints of both supplemented episodes were significantly discordant with the previous and following streamflow observations. Therefore, the missing values were derived using simple (ordinary least squares) linear regression based on data from the closest gauge with unexpectedly good results. In both cases, the reference period for estimating the regression function was set as the water that preceded the gap (1969 and 2002). For the interpolation of the AMM gauge data gap, the upstream station REH was used. Missing values in the KLI time series were interpolated based on data observed at the CHA gauging station. The calculations were conducted using following equations:

$$
\mathrm{Q}_{\mathrm{AMM}}=\left(2.4619 \mathrm{Q}_{\mathrm{REH}}\right)-0.038,
$$

where $Q_{A M M}$ represented mean daily discharge in Ammelsdorf and $Q_{R E H}$ stood for mean daily discharge in Rehefeld, and:

$$
\mathrm{Q}_{\mathrm{KLI}}=\left(2.2257 \mathrm{Q}_{\mathrm{CHA}}\right)+0.299,
$$

where $\mathrm{Q}_{\mathrm{KLI}}$ stood for mean daily discharge in Klingenthal and $\mathrm{Q}_{\mathrm{REH}}$ represented mean daily discharge at Chaloupky. The coefficient of determination $\left(R^{2}\right)$ was 0.885 for Equation (1) and 0.742 for Equation (2), proving a close relationship between AMM and REH discharge values as expected. In the case of the regression model of KLI and CHA, the resulting values were fair and did not exhibit any major discrepancies. Finally, the missing values were filled by the newly computed values and incorporated in both incomplete time series for further analyses as well as for the calculation of the principal streamflow and low-flow characteristics. Low flows and streamflow drought were defined by the Q90 and Q95 flow quantiles, representing, respectively, the discharge that is equaled or exceeded on $90 \%$ or $95 \%$ of all days within the observation period (Table 2). Moreover, mean annual specific discharges (qa) and specific low-flow (q90) and streamflow drought discharges (q95) representing the discharge standardized by the catchment area were calculated for a better comparison of the low-flow characteristics at various scales [43]. In study catchments with higher mean elevation, the values of $q$ a typically vary between approximately 23 and $37 \mathrm{~L} \mathrm{~s}^{-1} \mathrm{~km}^{-2}$, while lower sites experience qas ranging from 10 to $21 \mathrm{~L} \mathrm{~s}^{-1} \mathrm{~km}^{-2}$. Similar patterns can be also observed in specific low-flow discharges (e.g., q95), gauges with lower altitude usually exhibit values ranging from ca 2 to $4 \mathrm{~L} \mathrm{~s}^{-1} \mathrm{~km}^{-2}$, whereas values in montane catchments vary between ca 5.5 and $12 \mathrm{~L} \mathrm{~s}^{-1} \mathrm{~km}^{-2}$.

\subsection{Methods and Tools}

The methods applied in this study consist of multiple seasonality measures of low flows as well as techniques for quantification of their dynamics from a long-term perspective. Some of the following characteristics were calculated for 30-year moving averages within the 1968-2019 study 
period. This approach allows to examine the evolution and dynamics of minimum discharges, low flows and their seasonality in a more detailed resolution.

Table 2. Basic streamflow and low-flow properties of the study catchments during the 1968-2019 period. Data: CHMI, GKD Bayern, LfULG Sachsen.

\begin{tabular}{|c|c|c|c|c|c|c|c|c|c|}
\hline Gauge & $\begin{array}{c}\mathrm{Qa} \\
\left(\mathrm{m}^{3} \mathrm{~s}^{-1}\right)\end{array}$ & $\begin{array}{c}\text { Qmed } \\
\left(\mathrm{m}^{3} \mathrm{~s}^{-1}\right)\end{array}$ & $\begin{array}{c}\mathrm{qa} \\
\left(\mathrm{L} \mathrm{s}^{-1} \mathrm{~km}^{-2}\right)\end{array}$ & $\begin{array}{c}\mathrm{Q} 90 \\
\left(\mathrm{~m}^{3} \mathrm{~s}^{-1}\right)\end{array}$ & $\begin{array}{c}\text { Q95 } \\
\left(\mathrm{m}^{3} \mathrm{~s}^{-1}\right)\end{array}$ & $\begin{array}{c}\mathrm{q} 90 \\
\left(\mathrm{~L} \mathrm{~s}^{-1} \mathrm{~km}^{-2}\right)\end{array}$ & $\begin{array}{c}\mathrm{q95} \\
\left(\mathrm{L} \mathrm{s}^{-1} \mathrm{~km}^{-2}\right)\end{array}$ & $\begin{array}{l}\text { MAM-30 } \\
\left(\mathrm{m}^{3} \mathrm{~s}^{-1}\right)\end{array}$ & $\begin{array}{l}\text { MAM-7 } \\
\left(\mathrm{m}^{3} \mathrm{~s}^{-1}\right)\end{array}$ \\
\hline BLA & 0.898 & 0.540 & 10.51 & 0.250 & 0.205 & 2.93 & 2.4 & 0.268 & 0.217 \\
\hline $\mathrm{KOL}$ & 1.170 & 0.840 & 12.76 & 0.360 & 0.290 & 3.93 & 3.16 & 0.410 & 0.340 \\
\hline MOD & 3.302 & 2.180 & 36.77 & 1.190 & 1.050 & 13.25 & 11.69 & 1.271 & 1.086 \\
\hline $\mathrm{HOL}$ & 0.797 & 0.535 & 13.31 & 0.282 & 0.246 & 4.71 & 4.11 & 0.321 & 0.245 \\
\hline LIN & 2.241 & 1.560 & 24.98 & 0.815 & 0.714 & 9.09 & 7.96 & 0.836 & 0.723 \\
\hline $\mathrm{CHA}$ & 0.560 & 0.400 & 27.92 & 0.170 & 0.133 & 8.47 & 6.63 & 0.183 & 0.146 \\
\hline ROT & 1.403 & 0.920 & 18.44 & 0.332 & 0.260 & 4.36 & 3.42 & 0.360 & 0.283 \\
\hline $\mathrm{REH}$ & 0.361 & 0.194 & 23.44 & 0.061 & 0.040 & 3.96 & 2.6 & 0.072 & 0.051 \\
\hline AMM & 0.939 & 0.570 & 19.05 & 0.170 & 0.116 & 3.45 & 2.35 & 0.183 & 0.131 \\
\hline JAN & 1.914 & 1.140 & 37.30 & 0.544 & 0.450 & 10.6 & 8.77 & 0.590 & 0.467 \\
\hline DOL & 1.217 & 0.763 & 27.61 & 0.300 & 0.247 & 6.81 & 5.6 & 0.362 & 0.297 \\
\hline
\end{tabular}

Qa—mean annual discharge; $Q$ med—median annual discharge; $q a$-mean annual specific discharge; $Q 90$ — discharge with $90 \%$ exceedance probability; $Q 95$ - discharge with $95 \%$ exceedance probability; 990 - specific low-flow discharge based on Q90; 995-specific low-flow discharge based on Q95; MAM-30 - mean annual 30-day minimum discharge; MAM-7-mean annual seven-day minimum discharge.

The seasonality ratio (SR) $[25,31,43,44]$ describes the proportion between summer-specific low flows and streamflow droughts $\left(\mathrm{q} 90_{\mathrm{s}}\right.$ and $\left.\mathrm{q} 95_{\mathrm{s}}\right)$ and winter-specific low flows and streamflow droughts ( $\mathrm{q} 90_{\mathrm{w}}$ and $\mathrm{q} 95_{\mathrm{w}}$ ). For the SR calculation, the discharge series were divided into summer (1 April-30 November) and winter time series (1 December-31 March) in order to differentiate summer low flows caused by precipitation deficit and winter low-flow events caused by snow accumulation and frost in highland and montane areas. The SR values were then calculated for 23 periods of 30-year moving averages using the following equation:

$$
\mathrm{SR}_{\mathrm{q} 90}=\frac{\mathrm{q} 90_{\mathrm{s}}}{\mathrm{q} 90_{\mathrm{w}}} ; \mathrm{SR}_{\mathrm{q} 95}=\frac{\mathrm{q} 95_{\mathrm{s}}}{\mathrm{q} 95_{\mathrm{w}}}
$$

Values of the SR 1 indicate weak seasonality of streamflow drought during the year. SR values $>1$ are typical for the winter low-flow regime, whereas SR values closer to 0 indicate the summer low-flow regime.

The seasonality index (SI) represents the average seasonal distribution of low-flow and streamflow drought occurrence for the given period of time [43-45]. The SI is based on two parameters $(\Theta$ and $r)$ computed from the Julian dates of all observations when discharge values are under the threshold (Q90 or Q95). The parameter $\Theta$ represents a measure of the average seasonality of low flows by the average day of low-flow occurrence in radians (the values range from 0 to $2 \pi$, where 0 means January $1, \pi$ stands for 1 July and so forth). The parameter $\mathrm{r}$ represents the average resultant occurrence day and it is a dimensionless indicator of the low-flow seasonal variability. Values of $r$ range between 0 and 1 , where 0 means no seasonality of low flows (such events are evenly distributed throughout the year) and 1 corresponds to a very strong low-flow seasonality (every drought occurs every year on the same day). The days with discharge equal or below Q90 and Q95 were extracted over the study period (1968-2019) and transferred to Julian days $\left(D_{j}\right)$, which denote a cyclic variable displayable on the unit circle as a vector $[43,45]$. The directional angle in radians was then computed as follows:

$$
\Theta_{j}=\frac{D_{j} 2 \pi}{365}
$$


The mean of coordinates $x_{\Theta}$ and $y_{\Theta}$ of a sum of $n$ days $j$ was denoted as:

$$
\mathrm{x}_{\Theta}=\frac{1}{\mathrm{n}} \sum_{\mathrm{j}} \cos \left(\Theta_{\mathrm{j}}\right) ; \mathrm{y}_{\Theta}=\frac{1}{\mathrm{n}} \sum_{\mathrm{j}} \sin \left(\Theta_{\mathrm{j}}\right)
$$

Based on this, the angle of direction of the average vector was deducted by:

$$
\begin{gathered}
\Theta=\arctan \left(\frac{y_{\Theta}}{x_{\Theta}}\right) \text { first and fourth quadrants : } x>0 \\
\Theta=\arctan \left(\frac{y_{\Theta}}{x_{\Theta}}\right)+\pi \text { sec ond and third quadrants : } x<0
\end{gathered}
$$

The average day of low flow occurrence was then derived by transferring the average angle back to the Julian day format as follows:

$$
\mathrm{D}=\Theta \frac{365}{2 \pi}
$$

Finally, the average vector length $r$, which represents the variability of low-flow days, was derived:

$$
r=\sqrt{x_{\Theta}^{2}+y_{\Theta}^{2}}
$$

The combination of $r$ and $\mathrm{D}$ was then visualized in the polar graph for both Q90 and Q95 at every water gauge to figure the evolution of the average occurrence day during the study period along with its variability throughout the study period. These resulting values of the SI were depicted as 30-year moving averages to provide a smoothed picture of the evolution of low-flow seasonality.

All statistical analyses were done in R v4.0.3 [46]. The integral part of all calculations was conducted using the lfstat v0.9.4 [44] and trend v1.1.4 [47] packages. The lfstat package was developed for computing the statistics according to the Manual on Low-flow Estimation and Prediction published by the World Meteorological Organization (WMO), which gives a comprehensive summary on how to analyze streamflow data while focusing on low flows [44,48]. This package includes a wide variety of statistical components of low flows including the seasonality ratio (SR), seasonality index (SI), mean annual minima (MAM) and mean summer minima (MSM), identification of streamflow droughts with their deficit volumes and others.

After the evaluation of the general low-flow/drought seasonality, we focused on the summer streamflow drought events occurring between 1 April and 30 November. The drought duration and deficit volumes at every water-gauging station were derived using the varying monthly Q95 threshold. The minimum length of the events was set to seven consecutive days, while only the events characterized by deficit volumes equal to or greater than $0.5 \%$ of the maximum volume found for the respective station were kept. The sequent peak algorithm (SPA) was employed in order to exclude the minor exceedances of the thresholds $[49,50]$. Eventually, the annual sums of the deficits were standardized by the catchment area for a better comparison between each site and region resulting in values of runoff height deficit in liters per square meter $\left(\mathrm{L} \mathrm{m}^{-2}\right)$.

The trend package was used for detecting and examining statistical significance of trends (by the Mann-Kendall nonparametric test along with Sen's slope estimator [29,51-53]) in the time series of 30- and seven-day mean summer minimum discharges (MSM-30; MSM-7) computed again for the period of the year between 1 April and 30 November. The presence and the direction of monotonic trends in the data series of MSM-30 and MSM-7 were then tested at the significance level $\alpha=0.05$. 


\section{Results}

\subsection{Evolution of Low-Flow and Streamflow Drought Seasonality}

Long-term average values of the seasonality ratio (SR) provide a generalized information about the characteristics for the whole study period (Table 3). The average SR for $q 90$ and $q 95$ ranged from 0.45 to 1.2 and 0.49 to 1.14 , respectively. This indicates that the low-flow and drought regime in most of the catchments is closer to the summer type, but the seasonality is generally weak with values close to 1 . The only catchment with SR > 1 for both q90 and q95 is MOD, suggesting that the winter low flows are slightly prevalent in this catchment.

Table 3. Average values of the seasonality ratio (SR) for the 1968-2019 period.

\begin{tabular}{llllllllllllllll}
\hline \multicolumn{1}{c}{ Southwestern Region (SW) } & \multicolumn{4}{c}{ Northwestern Region (NW) } & \multicolumn{3}{c}{ Northeastern Region (NE) } \\
\hline & BLA & KOL & MOD HOL & LIN & LOH & KLI & CHA & ROT & REH & AMM & JAN & DOL & HOR & MAR \\
\hline SR (q90) & 0.85 & 0.85 & 1.20 & 0.70 & 0.85 & 0.91 & 0.59 & 0.94 & 0.62 & 0.50 & 0.45 & 0.97 & 0.83 & 1.01 & 0.82 \\
SR (q95) & 0.82 & 0.80 & 1.14 & 0.70 & 0.87 & 0.92 & 0.57 & 1.12 & 0.62 & 0.57 & 0.49 & 0.91 & 0.79 & 0.97 & 0.84 \\
\hline
\end{tabular}

The evolution of the SR was visualized by the 30-year moving averages. In most of the study catchments, the SR derived from the q90 series (Figure 2a) was generally decreasing in all regions with two exceptions (MOD in SW; HOR in NE), where the SR values remained relatively stable in the long-term horizon. The steepest decline was observed in most catchments of the NW region as well as in two catchments of the NE region (JAN, DOL). In most of the study catchments, the variability of SR calculated using the q95 series (Figure 2b) was distinctly greater, but the pattern of a decrease towards the summer low-flow regime was still apparent. Unlike the SR of the q90 series, all water gauges including MOD and HOR exhibited a decline even though the values varied significantly throughout the whole analyzed period. Assuming that the threshold between the winter and the summer low-flow regime was defined as $S R=1$, eight out of fifteen catchments experienced a transition from the winter low-flow regime to the summer regime during the 1968-2019 period.

Long-term average values of the seasonality index (SI) components present the information about the characteristics for the complete 1968-2019 period (Table 4). In the catchments, the average occurrence of low flows (Q90) varied from 23 August to 8 December. The parameter r, which describes the concentration of the low-flow events during the year, ranged from 0.31 to 0.63 .

The average occurrence of streamflow droughts (Q95) ranged from 18 August to 20 December, while the values of the parameter $r$ varied between 0.38 and 0.71 , meaning that the streamflow drought events (Q95) were generally slightly more concentrated in comparison with the low-flow events (Q90).

The 30-year SI moving averages for both Q90 and Q95 were plotted in polar graphs in order to visualize the joint evolution of the average low-flow/drought occurrence date along with the parameter $r$ representing the level of concentration of such events during the year. In the catchments of the SW region (Figure 3), there is a common pattern of the increasing concentration of low flows and streamflow droughts. The most pronounced change of the concentration was observed in BLA and KOL, where the 30-year average values of the parameter $\mathrm{r}$ (Q95) rose from 0.25-0.35 to 0.7-0.8, whereas in the other catchments the increase was rather small. Changes were detected also in the average date of low-flow/drought occurrence. The most marked shift was observed in $\mathrm{LOH}$, where the average day of Q95 occurrence moved by 74 days towards the beginning of the year, while in MOD, the shift was only six days. In all catchments of the SW region, the changes in the SI components were more eminent when using the Q95 quantile. 
Table 4. Average values of the seasonality index (SI) components for the 1968-2019 period.

\begin{tabular}{|c|c|c|c|c|c|c|c|c|c|c|c|c|c|c|c|}
\hline & \multicolumn{6}{|c|}{ Southwestern Region (SW) } & \multicolumn{5}{|c|}{ Northwestern Region (NW) } & \multicolumn{4}{|c|}{ Northeastern Region (NE) } \\
\hline & BLA & KOL & MOD & HOL & LIN & LOH & KLI & CHA & ROT & REH & AMM & JAN & DOL & HOR & MAR \\
\hline SI (Q90) $\Theta$ & 4.41 & 4.37 & 5.89 & 4.05 & 4.82 & 4.90 & 4.31 & 4.87 & 4.51 & 4.19 & 4.26 & 4.72 & 4.52 & 5.01 & 4.74 \\
\hline SI (Q90) r & 0.41 & 0.40 & 0.39 & 0.62 & 0.56 & 0.42 & 0.59 & 0.38 & 0.62 & 0.55 & 0.63 & 0.31 & 0.47 & 0.36 & 0.48 \\
\hline SI (Q90) D & 256 & 254 & 342 & 235 & 280 & 284 & 250 & 283 & 262 & 244 & 248 & 274 & 262 & 291 & 275 \\
\hline \multirow[t]{2}{*}{ SI (Q90) Date } & 13 & 11 & 8 & 23 & 7 & 11 & 7 & 10 & 19 & 1 & 5 & 1 & 19 & 18 & 2 \\
\hline & September & September & December & August & October & October & September & October & September & September & September & October & September & October & October \\
\hline SI (Q95) $\Theta$ & 4.33 & 4.27 & 6.10 & 3.95 & 4.77 & 4.88 & 4.27 & 5.03 & 4.57 & 4.21 & 4.38 & 4.56 & 4.48 & 5.04 & 4.79 \\
\hline SI (Q95) r & 0.51 & 0.59 & 0.45 & 0.69 & 0.59 & 0.40 & 0.70 & 0.38 & 0.69 & 0.52 & 0.71 & 0.47 & 0.58 & 0.45 & 0.60 \\
\hline SI (Q95) D & 252 & 248 & 354 & 230 & 277 & 284 & 248 & 292 & 265 & 245 & 254 & 265 & 260 & 293 & 278 \\
\hline \multirow[t]{2}{*}{ SI (Q95) Date } & 9 & 5 & 20 & 18 & 4 & 11 & 5 & 19 & 22 & 2 & 11 & 22 & 17 & 20 & 5 \\
\hline & September & September & December & August & October & October & September & October & September & September & September & September & September & October & October \\
\hline
\end{tabular}


a)

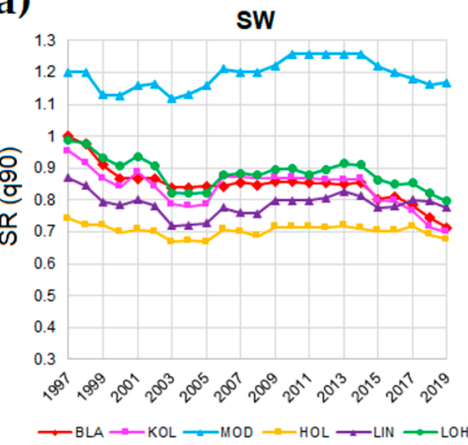

b)

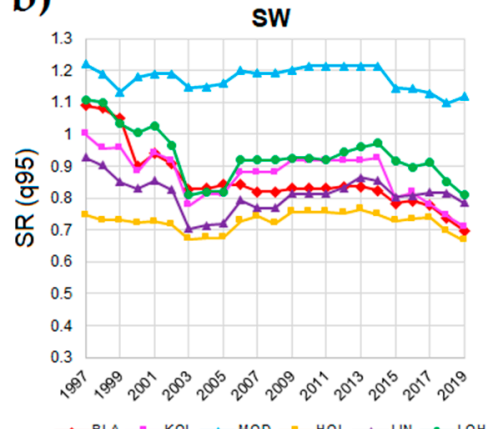

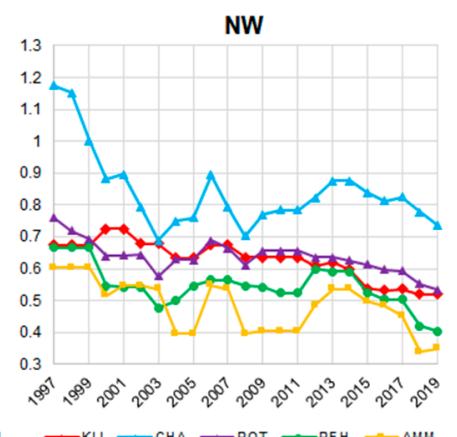

NW

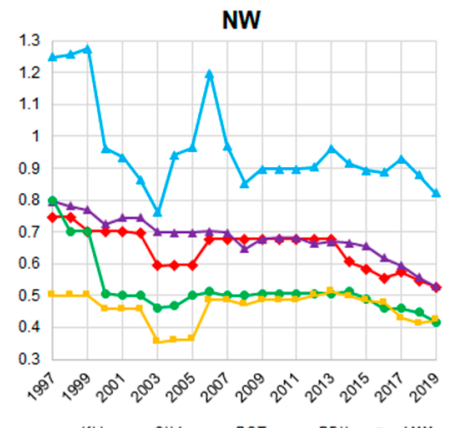

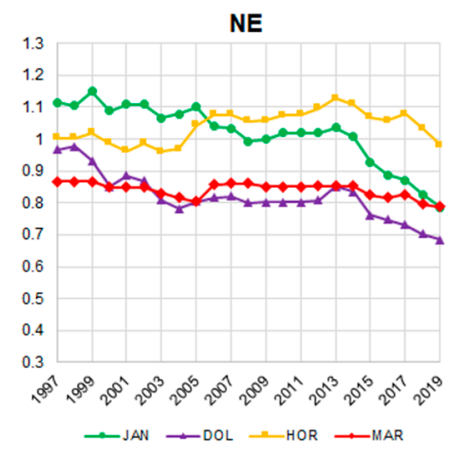

NE

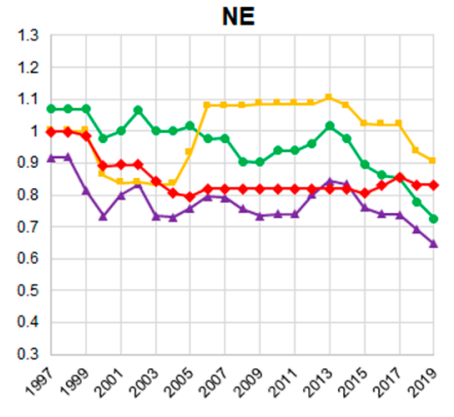

Figure 2. Evolution of the 30-year moving seasonality ratio (SR) at the water-gauging stations derived from (a) the $\mathrm{q} 90$ and (b) the $\mathrm{q} 95$ time series. Labels on the $\mathrm{x}$ axis represent the end year of every 30 -year period (1997 represents the 1968-1997 period and so forth).
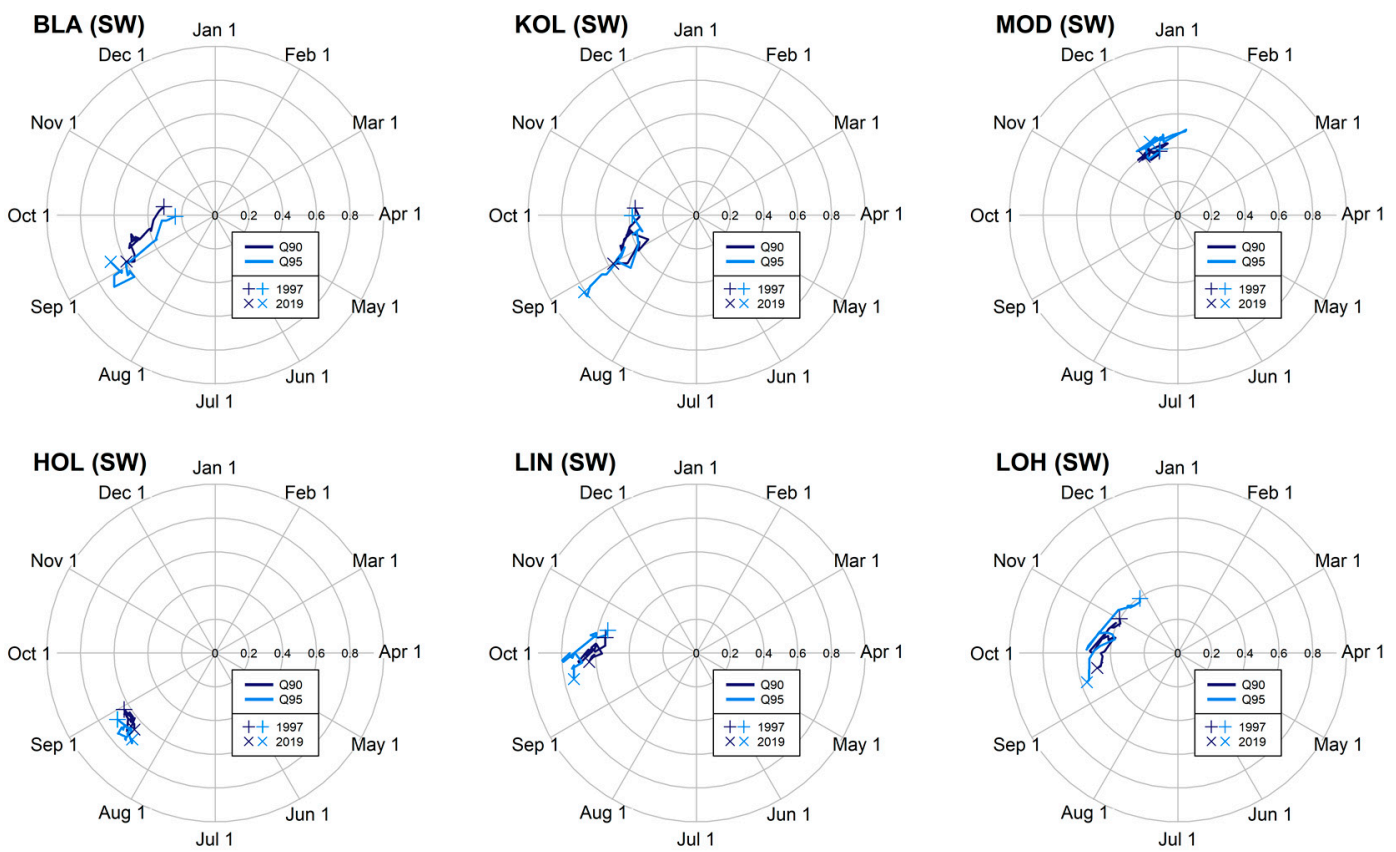

Figure 3. Evolution of the SI (Date and r) using the 30-year moving average of Q90 (dark blue) and Q95 (light blue) in catchments within the SW region. Curves denote the evolution of SI in time, symbols represent the first (1968-1997) and the last (1990-2019) period of the 30-year SI average.

In the analyzed catchments of the NW and the NE region (Figure 4), the shifts in the values of SI components were more apparent for the Q95 quantile than for the Q90 quantile, similar to the situation 
in the SW region. The pattern of the increasing concentration of low flows and streamflow droughts was also present in all catchments of both regions. The most distinct shift in the average concentration of drought events occurrence was observed in REH (NW) and JAN (NE), where the values of the parameter $\mathrm{r}(\mathrm{Q} 95)$ rose by 0.41 and 0.44 , respectively. In contrast, the smallest increase was detected in AMM (NW) and HOR (NE), where the parameter $r$ rose by 0.13 and by 0.16 , respectively.
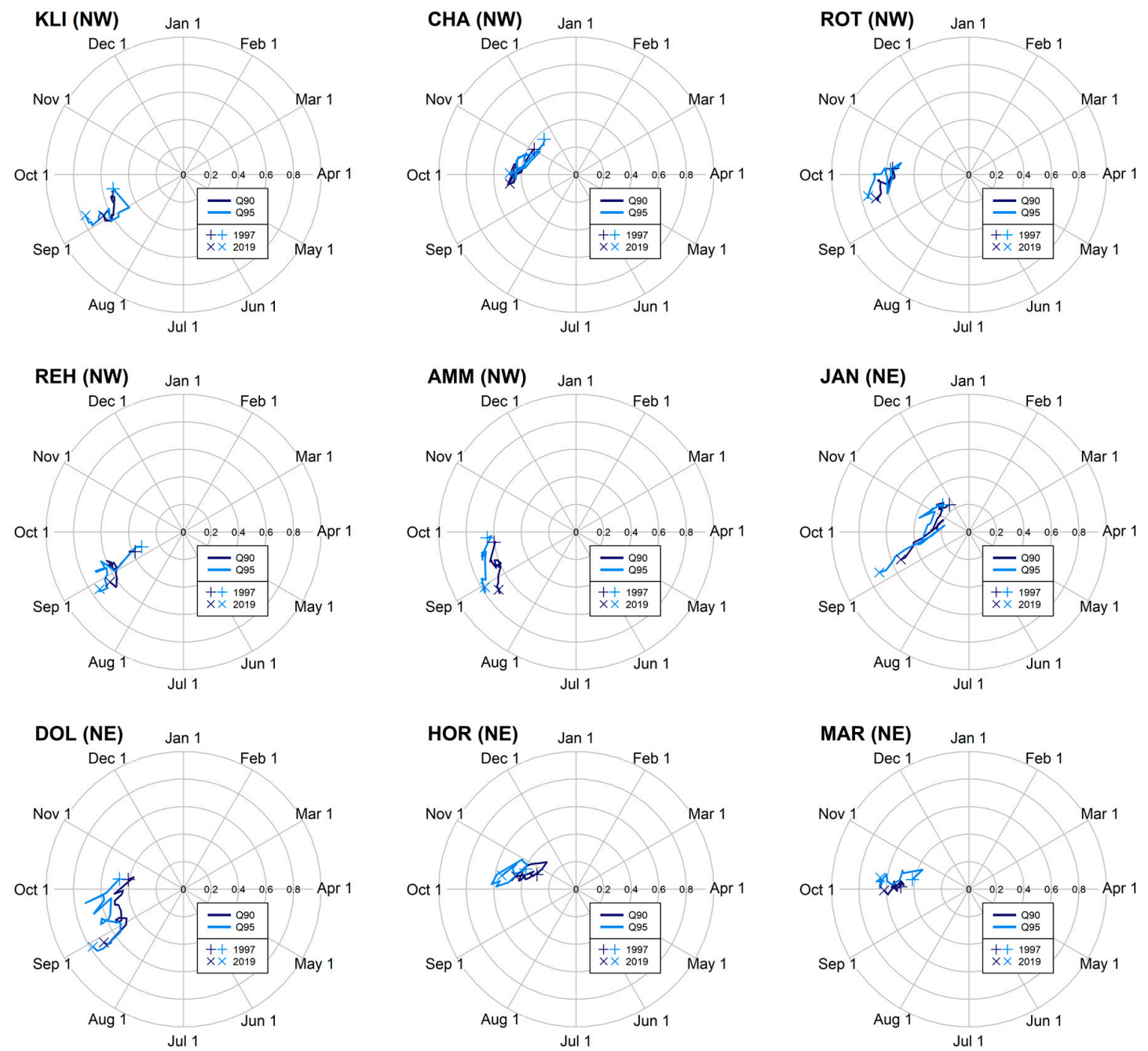

Figure 4. Evolution of the SI (Date and r) using the 30-year moving average of Q90 (dark blue) and Q95 (light blue) in catchments of NW and NE regions. Curves denote the evolution of SI in time, symbols represent the first (1968-1997) and the last (1990-2019) period of 30-year moving average.

The differences between catchments in terms of the average date of streamflow drought occurrence were rather distinct even within the individual regions. The most significant shift in the NW region was detected in CHA. The average day of Q95 occurrence moved in this catchment by 47 days towards the start of the year, whereas in KLI the shift was 11 days in the same direction. In the NE region, the most eminent shift was recorded in JAN (71 days), while in MAR, the shift was nearly negligible with only two days.

On average, for all study catchments, the increase of the parameter $r(Q 95)$ between the periods 1968-1997 and 1980-2019 was 0.24 and the average shift in streamflow drought occurrence was 28 days towards the start of the year. The catchments MOD, HOL and HOR were assessed as the most stable catchments regarding both seasonality parameters during the analyzed period. 


\subsection{Duration and Magnitude of Summer Streamflow Droughts Events}

In general, the results of the seasonality analyses indicated that the streamflow drought events in the study catchments have an ongoing tendency to concentrate more in the warmer parts of the year. To quantify the real impact of the changing seasonal distribution of streamflow droughts, we examined the duration and deficit volumes of the actual streamflow drought events occurring within the summer season (1 April-30 November) in the catchments during the 1968-2019 period.

In four catchments within the SW region (BLA, MOD, HOL and LOH), the longest streamflow drought event was in 2018. In KOL and LIN, the longest drought events occurred in 2015 and in 1983, respectively. The other long-lasting streamflow droughts occurred in years 2014 (the third longest in KOL and LIN), 2015 (the second longest in BLA and MOD), and in 2019 (the second longest in HOL, LIN and the third longest in BLA, HOL and LOH). Regarding the magnitudes of streamflow droughts, the driest episodes occurred in 2018 (BLA, MOD and LOH), in 1991 (LOH), in 2015 (KOL and MOD) and in 2014 (LIN, KOL and LOH). In general, the drought episodes in BLA, KOL, MOD and LOH were longer and more severe by the end of the study period, whereas in LIN and LOH, the temporal distribution of the longest and the most intense droughts is more variable (Figure 5). The longest period of drought along with the greatest magnitude in the SW region was measured during the 2018 summer season in $\mathrm{LOH}$, a total of 168 days and a $29.5 \mathrm{~L} \mathrm{~m}^{-2}$ runoff height.
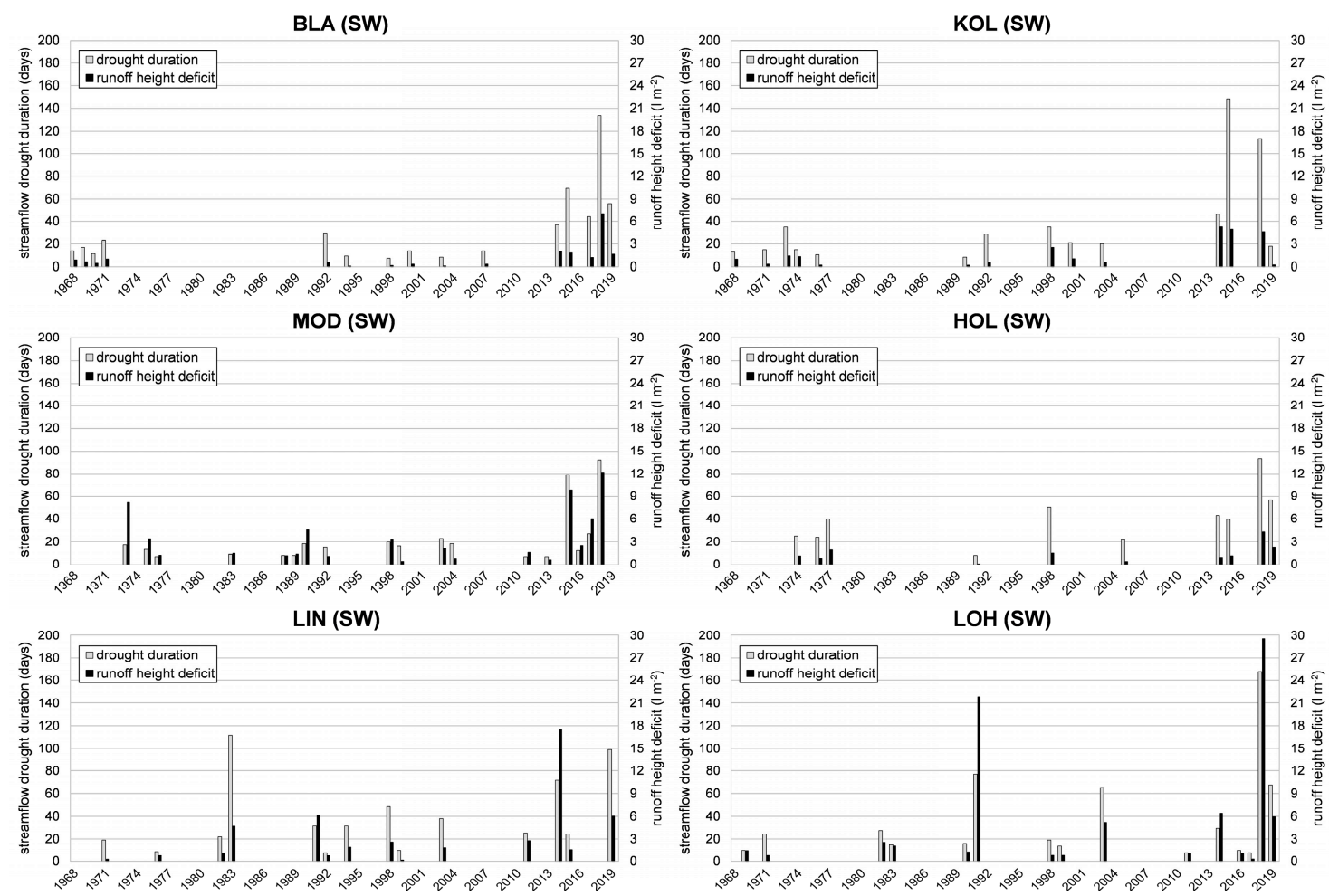

Figure 5. Duration and runoff height deficits of streamflow drought events in the catchments of the SW region during the 1968-2019 period.

The longest streamflow drought event was recorded in four catchments of the NW region (KLI, ROT, REH and AMM) in 2018 (Figure 6). In the CHA catchment, the longest drought was recorded in the summer of 2003, which was also one of the driest years in KLI, ROT and AMM. The other long-lasting streamflow droughts occurred during the summer seasons of 2015 (the second longest in KLI), 2014 (KLI and CHA), 1975 in REH and 1976 in AMM. Regarding the magnitudes of streamflow droughts, the driest episodes occurred in 2014 and 2003 in the CHA catchment, in 2018 (KLI and ROT), in 1975 (REH) and in 1976 (AMM). Generally, the periods of streamflow drought in KLI, CHA and ROT were longer and more severe during the second half of the study period, while in REH and AMM the 
episodes were distributed more evenly across the 1968-2019 period. The longest drought in the NW region was recorded during the 2018 summer season in ROT (187 days). As for the drought magnitude, the greatest runoff height deficit was observed in CHA in the summer of $2014\left(12.4 \mathrm{~L} \mathrm{~m}^{-2}\right)$.
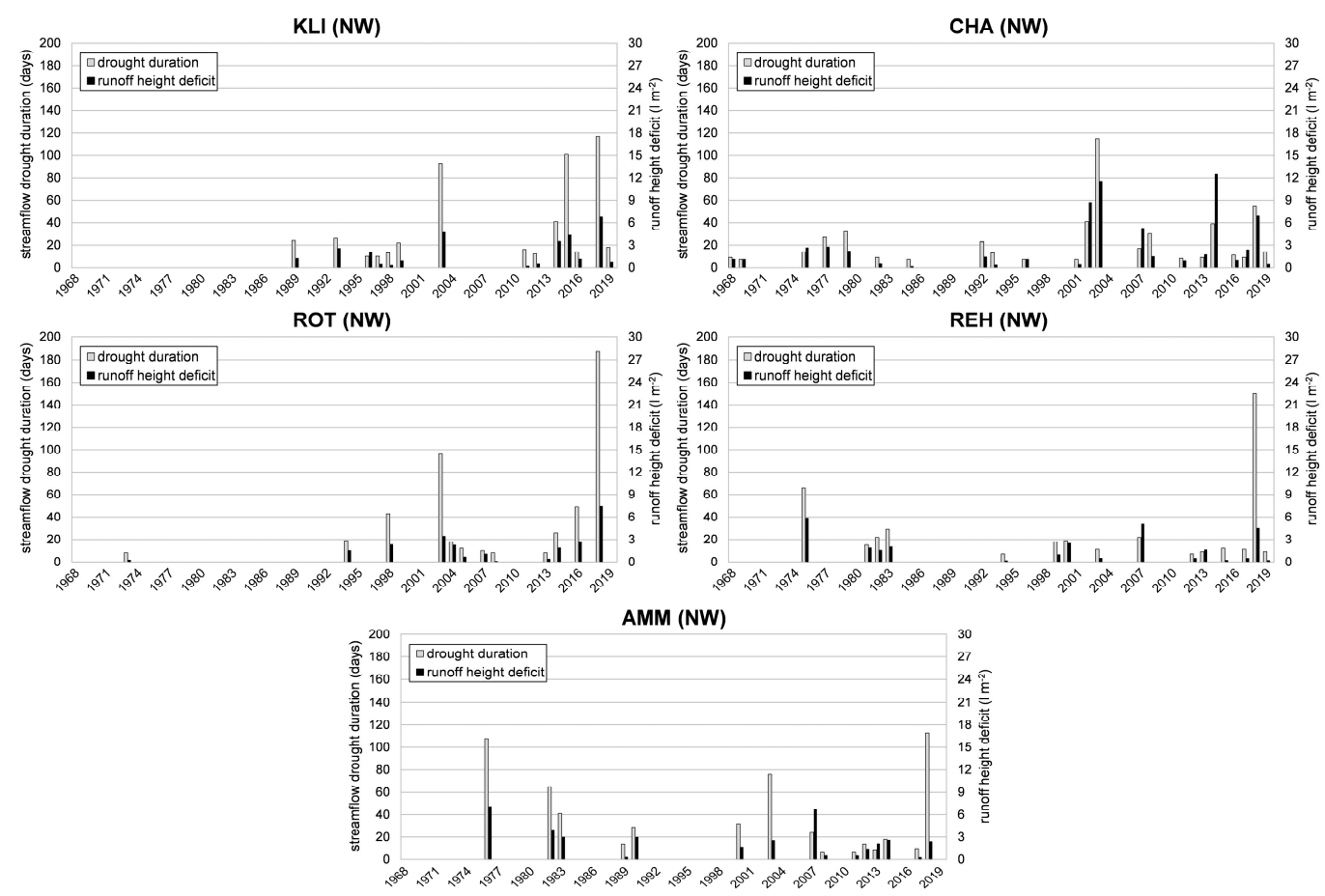

Figure 6. Duration and runoff height deficits of streamflow drought events in the catchments of the NW region during the 1968-2019 period.

In the NE region, the longest streamflow drought was observed during the 2018 summer season in JAN, HOR and MAR (Figure 7). In the DOL catchment, the longest drought was recorded in the summer of 1983, which was also one of the driest years in JAN and HOR. The further remarkable streamflow droughts occurred in 1971 (DOL), 1976 (DOL), 1990 (JAN, DOL, HOR), 2003 (MAR), 2015 (JAN, HOR, MAR) and 2019 (JAN).
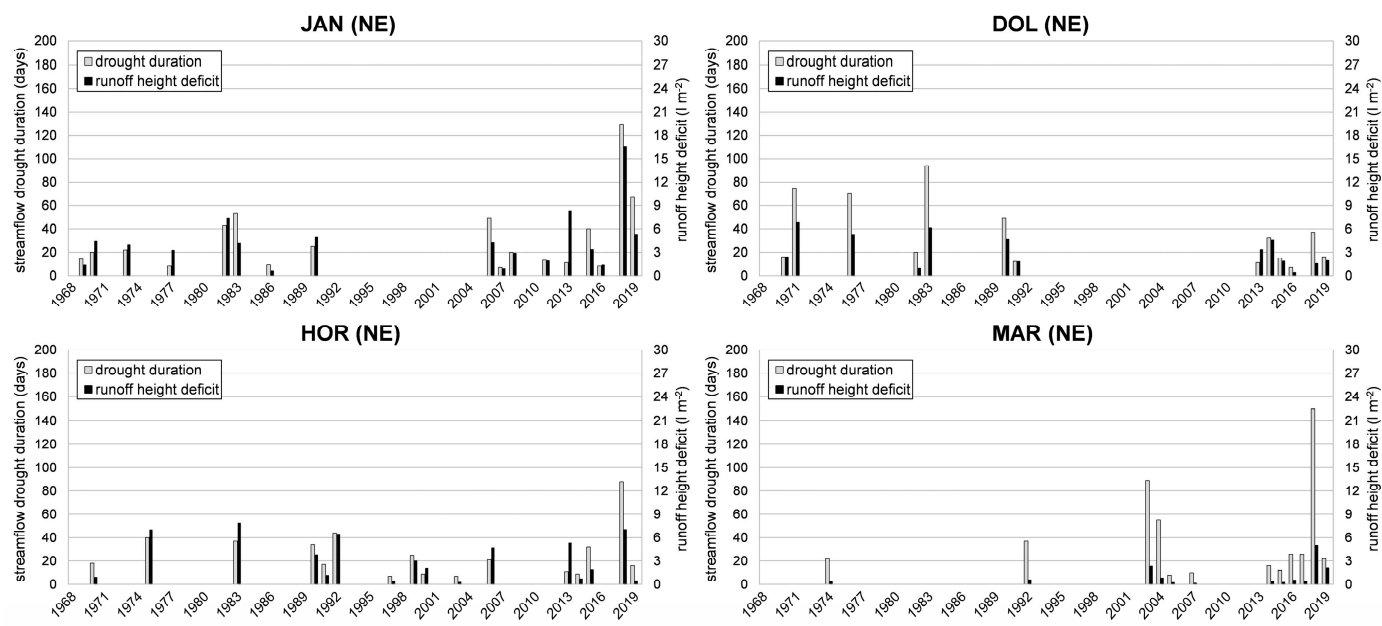

Figure 7. Duration and runoff height deficits of streamflow drought events in the catchments of the NE region during the 1968-2019 period.

Regarding the magnitudes of streamflow droughts, the driest episodes occurred in 2018 (JAN, HOR, MAR), 1971 (DOL) and 1983 (HOR). In general, the streamflow drought events in JAN and 
HOR occurred relatively regularly with similar strength, whereas the droughts in MAR were more concentrated in the second half of the study period. The longest streamflow drought period within the NE region was recorded during the 2018 summer season in MAR (150 days) and the largest runoff height deficit was observed in JAN during the same year $\left(16.5 \mathrm{~L} \mathrm{~m}^{-2}\right)$.

\subsection{Trends of Minimum Discharges}

The trend analysis based on the series of mean summer minimum discharge (MSM-30; MSM-7) computed for the period from 1 April to 30 November was performed for all study catchments for the whole study period (Table 5) as well as for the 30-year moving windows.

Table 5. The significance and direction of trends in the MSM-30 and MSM-7 time series (1968-2019) derived by the Mann-Kendall test. Trends are highlighted by three shades of orange (decrease) according to their statistical significance (no color for $p \geq 0.05$; light for $p<0.05$; medium for $p<0.01$; dark for $p<0.001)$ along with the direction of Sen's slope estimate $(+$ and - ).

\begin{tabular}{ccccccccccccccccc}
\hline & \multicolumn{4}{c}{ Southwestern Region (SW) } & \multicolumn{3}{c}{ Northwestern Region (NW) } & $\begin{array}{c}\text { Northeastern Region } \\
\text { (NE) }\end{array}$ \\
\hline & BLA & KOL & MOD HOL & LIN & LOH & KLI & CHA & ROT & REH & AMM JAN & DOL HOR MAR \\
\hline MSM-30 & - & - & - & - & - & - & - & - & - & - & - & - & + & - & - \\
MSM-7 & - & - & - & - & - & - & - & - & - & - & - & - & + & - & - \\
\hline
\end{tabular}

The trend analysis of the MSM-30 series showed that a statistically significant $(p<0.05)$ decrease was detected only in five catchments (BLA, KOL, KLI, ROT and MAR). When testing the MSM-7 data series, the significant decline in MSM-7 was shown only in KLI, ROT and MAR. Moreover, there were not any significant trends in the SW region. The only catchment with long-term increasing tendency in both series was DOL; however, the trend was not significant.

The results of the trend analysis for the 30-year moving windows of MSM-30 (Table 6) showed a rather diverse pattern. The only two catchments with steadily decreasing tendency during the whole 1968-2019 period were ROT and KLI with the most significant decreases between 1974 and 2009 as well as in the intervals at the end of the study period.

Table 6. The significance and direction of trends derived for the 30-year moving windows of the MSM-30 series by the Mann-Kendall test. Trends are highlighted by three shades of orange (decrease) and blue (increase) according to their statistical significance (no color for $p \geq 0.05$; light for $p<0.05$; medium for $p<0.01$; dark for $p<0.001$ ) along with the direction of Sen's slope estimate (+ and - ).

\begin{tabular}{|c|c|c|c|c|c|c|c|c|c|c|c|c|c|c|c|}
\hline \multirow[b]{2}{*}{ Period } & \multicolumn{6}{|c|}{ Southwestern Region (SW) } & \multicolumn{5}{|c|}{ Northwestern Region (NW) } & \multicolumn{4}{|c|}{ Northeastern Region (NE) } \\
\hline & BLA & KOL & MOD & HOL & LIN & LOH & KLI & CHA & ROT & REH & AMM & JAN & DOL & HOR & MAR \\
\hline 1968-1997 & - & - & - & + & + & + & - & + & - & + & + & + & + & - & - \\
\hline 1969-1998 & - & - & + & - & - & + & - & + & - & + & + & + & + & + & + \\
\hline 1970-1999 & - & - & + & - & - & + & - & + & - & - & + & + & + & - & - \\
\hline 1971-2000 & - & - & - & + & - & - & - & + & - & - & + & + & + & - & - \\
\hline 1972-2001 & - & - & - & - & - & - & - & + & - & - & - & + & + & - & - \\
\hline 1973-2002 & - & - & - & + & - & - & - & + & - & - & + & + & + & + & - \\
\hline 1974-2003 & - & - & - & - & - & - & - & - & - & - & + & + & + & - & - \\
\hline 1975-2004 & - & - & - & - & - & - & - & - & - & - & + & + & + & - & - \\
\hline 1976-2005 & - & - & - & - & - & - & - & - & - & - & + & + & + & - & - \\
\hline 1977-2006 & - & - & - & - & - & - & - & - & - & - & - & + & + & - & - \\
\hline 1978-2007 & - & - & - & - & - & - & - & - & - & - & - & + & + & - & - \\
\hline 1979-2008 & - & - & - & - & - & - & - & - & - & - & - & + & + & + & - \\
\hline 1980-2009 & - & - & - & - & + & + & - & - & - & - & + & + & + & + & - \\
\hline 1981-2010 & - & + & - & - & + & + & - & - & - & - & + & + & + & + & - \\
\hline 1982-2011 & - & + & + & + & + & + & - & + & - & + & + & + & + & + & - \\
\hline 1983-2012 & + & + & + & + & + & + & - & - & - & - & + & + & + & + & - \\
\hline 1984-2013 & + & + & + & + & - & + & - & - & - & - & + & - & - & + & - \\
\hline 1985-2014 & - & + & + & - & - & + & - & - & - & - & - & - & - & + & - \\
\hline 1986-2015 & - & + & + & - & - & + & - & - & - & - & - & - & - & + & - \\
\hline $1987-2016$ & - & + & + & - & - & + & - & - & - & - & - & - & - & + & - \\
\hline 1988-2017 & - & + & + & - & - & + & - & - & - & - & - & - & - & + & - \\
\hline 1989-2018 & - & + & - & - & - & - & - & - & - & - & - & - & - & + & - \\
\hline 1990-2019 & - & - & - & - & - & - & - & - & - & - & - & - & - & + & - \\
\hline
\end{tabular}


In contrast, the values of MSM-30 were significantly increasing in DOL until 2005, making it the only catchment with significant increases during the whole study period. Moreover, DOL was also the only catchment which exhibited both significant increase and decrease, indicating an overall transition of the MSM-30 trend direction.

In general, statistically significant negative trends prevailed during the first half of the study period in the SW region, while the negative trends in the NW and NE region were more concentrated in the middle and at the end of the 1968-2019 period. The significant decrease during the 1977-2006 and 1978-2008 interval was detected in seven and six catchments across the study regions. The results also showed that there were six catchments across all study regions without a significant increasing or decreasing trend whatsoever (LIN, LOH, CHA, REH, AMM and HOR).

The results of the Mann-Kendall trend test for the MSM-7 series (Table 7) showed a relatively similar pattern to that of the MSM-30 series. Again, the only catchment observing the significant increasing trends was DOL. However, the significant increasing trends were detected only until 2004 and the transition to the significant decreasing trend took only 11 intervals instead of 13 detected in the MSM-30 series. The only catchments with decreasing MSM-7 during the whole 1968-2019 period were KLI, ROT and MAR with the most significant decreases between 1974 and 2010. In comparison with the trends in the MSM-30 series, the trend significance was slightly higher in KLI, ROT and MAR between 1977 and 2009. In ROT, JAN and DOL, the significant decreasing trends were detected also at the end of the analyzed period. In KLI, the significant declines were shown only in the first half of the study period. The results for MSM-7 showed no significant trends, either increasing or decreasing, in the same six catchments (LIN, LOH, CHA, REH, AMM and HOR).

Table 7. The significance and direction of trends derived for the 30-year moving windows of the MSM-7 series by the Mann-Kendall test. Trends are highlighted by three shades of orange (decrease) and blue (increase) according to their statistical significance (no color for $p \geq 0.05$; light for $p<0.05$; medium for $p<0.01$; dark for $p<0.001$ ) along with the direction of Sen's slope estimate ( + and - ).

\begin{tabular}{|c|c|c|c|c|c|c|c|c|c|c|c|c|c|c|c|}
\hline \multirow[b]{2}{*}{ Period } & \multicolumn{6}{|c|}{ Southwestern Region (SW) } & \multicolumn{5}{|c|}{ Northwestern Region (NW) } & \multicolumn{4}{|c|}{ Northeastern Region (NE) } \\
\hline & BLA & KOL & MOD & HOL & LIN & LOH & KLI & CHA & ROT & REH & AMM & JAN & DOL & HOR & MAR \\
\hline $1968-1997$ & + & - & - & + & - & + & - & + & - & + & + & + & + & - & - \\
\hline 1970-1999 & - & - & - & + & - & - & - & + & - & - & + & + & + & - & - \\
\hline 1971-2000 & - & - & - & + & - & - & - & + & - & - & + & + & + & - & - \\
\hline 1972-2001 & - & - & - & + & - & - & - & + & - & - & + & + & + & - & - \\
\hline 1975-2004 & - & - & - & - & - & - & - & + & - & - & + & + & + & - & - \\
\hline 1976-2005 & - & - & - & - & - & - & - & - & - & - & + & + & + & - & - \\
\hline 1977-2006 & - & - & - & - & - & - & - & - & - & - & + & + & + & - & - \\
\hline 1978-2007 & - & - & - & - & - & - & - & + & - & - & + & + & + & - & - \\
\hline 1979-2008 & - & - & - & - & - & - & - & - & - & - & + & + & + & + & - \\
\hline 1984-2013 & - & + & + & - & + & + & - & - & - & + & + & + & - & + & - \\
\hline 1985-2014 & - & + & + & - & - & + & - & - & - & + & + & - & - & + & - \\
\hline 1986-2015 & - & + & + & - & - & + & - & - & - & - & - & - & - & + & - \\
\hline 1987-2016 & - & + & + & - & - & + & - & - & - & - & - & - & - & + & - \\
\hline 1988-2017 & - & + & + & - & - & + & - & - & - & + & - & - & - & + & - \\
\hline 1989-2018 & - & - & - & - & - & + & - & - & - & - & - & - & - & + & - \\
\hline 1990-2019 & - & - & - & - & - & - & - & - & - & - & - & - & - & + & - \\
\hline
\end{tabular}

The evaluation of trends in the 30-year steps of MSM-30 and MSM-7 provided a more synoptic image of the evolution and variability of the low-flow tendencies inside the 1968-2019 period. Furthermore, in the catchments of MOD, HOL, DOL, JAN and MAR, there were multiple 30-year intervals with a significant trend signal which showed the nonuniformity in the evolution of mean summer minimum flows as well as the most pronounced periods of change. 


\section{Discussion}

The results of analyses of changes in the long-term variability and seasonality of low flows and streamflow droughts in 15 headwater, near-natural catchments of five different mountain ranges and highlands within the Central European region showed that not all of the established hypotheses can be sufficiently confirmed.

A shift in the seasonality ratio (SR) of low flows and streamflow droughts was apparent in most of the studied catchments. In two catchments with the average altitude above 1000 m.a.s.l. (MOD, HOR), the change was negligible suggesting that the ratio between summer and winter low flows remained almost the same at these sites throughout the 1968-2019 period. The relative stability of these two catchments during the study period is supported by the lowest average temperatures and the largest proportion of snow cover influencing the summer low flows [18,54], indicating that the warming has not significantly influenced the overall runoff balance of most montane catchments yet [12,27]. However, multiple studies suggest a further decrease in snow cover depth and snow water equivalent in montane areas of Central Europe, leading to a decrease in snowmelt contribution to summer runoff in the near future [27,31]. The most dynamic shifts were observed in the catchments with the mean elevation between 800 and 1000 m.a.s.l. A typical pattern for these catchments was a gradual decline in rates of winter low flows and streamflow droughts, which indicates that the consecutive warming in Central Europe affects these particular catchments the most. Catchments with the average elevation below 750 m.a.s.l. experienced generally just a minor decrease in values of the SR.

The changes in seasonality index (SI) differed among the study catchment as well. The behavior of the SI evolution during the analyzed period was in concordance with the evolution of SR. On average, the mean date of low flows has moved by approximately one month towards the start of the year. The most eminent shifts in the average low-flow date were detected in the catchments with the average altitude $~ 900$ m.a.s.l. and with the prevailing hillslopes with S, SW and W direction across all of the study regions. Moreover, the low-flow and drought events exhibited an increasing tendency to occur in the same parts of the year within these catchments $[4,10,31]$. The two highest (MOD, HOR) and the two lowest (MAR, HOL) catchment showed minor changes in the average date of low-flow/drought occurrence during the 1968-2019 period.

The temporal distribution, duration and magnitude of the summer streamflow drought events were examined using the monthly (i.e., seasonally varying) threshold. Although the recent years, including 2018 and 2015 [14,20,21], have shown an increased occurrence of long-lasting severe droughts [8,11], this pattern may not be entirely valid for all of the study catchments. In some of them, the largest deficit volumes were observed during summer droughts in the 1970s and 1980s. The occurrence of summer streamflow droughts in Central Europe is also strongly dependent on the amount of snowpack in the previous winter $[18,19]$. Indeed, the recent long-lasting streamflow droughts indicate the potential increased proneness to such events in more than a half of the selected study catchments [25,26]. For a more representative assessment of droughts derived on the basis of the Q95 threshold and other necessary criteria, it would be better to use longer time series in order to make the resulting datasets less sparse [54-56]. However, such an approach would significantly affect the number of available catchments in this study because the areas of interest, mainly in the Ore Mountains (NW), have been gauged mostly since the 1960s.

Moreover, the effect of land cover changes in the catchments affected by forest disturbance might further enhance the effect of climate warming. Forest disturbances have an important role in snowmelt rates which might further affect the seasonal distribution of low flows [57]. Recent forest disturbances in the Ore Mountains [58] and the Bohemian Forest, caused predominantly by the infestation of bark beetle $[28,30]$, should also indicate the streamflow feedback in the conditions of multiple changes of the environment in the near future [59-61]. The change points in long-term air temperature series detected in various studies between 1985 and 1995 [22,54,62] have been followed by increased frequency and intensity of low-flow events. This was further supported by our results, since the longest and most severe streamflow droughts occurred after 2000 in the major part of analyzed catchments. For most of 
the low-flow characteristics, there was no distinct difference between the regions, the similarities in low-flow regime were mostly found in the catchments with analogical properties across all regions. The initiation and persistence of streamflow droughts can be more dependent on local circulation of subsurface and surface water than on regional meteorological conditions [4]. Therefore, it seems to be crucial to further examine the reciprocal effects of the changing climate and the environmental characteristics of the near-natural catchments to clarify the mechanisms of runoff regime changes

\section{Conclusions}

The main objective of this paper was to evaluate the seasonality, magnitude and trends of selected low-flow and streamflow drought characteristics in five Central European montane and highland regions. We provided a comparison of different low-flow characteristics and seasonality indicators computed on the basis of daily streamflow data series in the 1968-2019 period in a set of fifteen near-natural headwater catchments located along the Czech-German and the Czech-Polish borders.

The outputs of this study, to some extent, confirmed the hypotheses that assumed the influence of the ongoing regional climate change on the ratio between summer and winter low flows and consequent changes in the seasonal distribution of low flows and streamflow droughts during the analyzed period.

We have shown a substantial reduction in the proportion of winter low-flow events expressed by the declining values of the seasonality ratio (SR) in the majority of study catchments. The regions with the highest average altitude appeared to be the most stable in terms of the balance between summer and winter low flows. Consequently, the results have proven the apparent shift in the low-flow and streamflow drought seasonality quantified by the components of the seasonality index (SI). In all study regions, the most pronounced seasonality shifts were detected in catchments oriented predominantly to the southwest and characterized by the mean altitude 800-1000 m.a.s.l. The hypothesis expecting a significant decrease in the mean summer minimum discharges in most of study catchment was not confirmed.

In this paper, only the hydrological characteristics were analyzed to provide an overview of the low flows and streamflow drought characteristics in fifteen headwater catchments in three regions of Central Europe. For a representative drought frequency analysis of low flows and droughts in the future, the catchments with the longest available streamflow data series should be chosen. Thereby, the following direction of research should also involve a detailed set of local climatic data in order to clarify the response of the low-flow regime in particular catchments.

Author Contributions: Conceptualization, V.V., O.L. and M.M.; methodology, V.V. and O.L.; software, V.V. and O.L.; validation, V.V., O.L. and M.M.; formal analysis, V.V.; investigation, V.V. and O.L.; resources, V.V., O.L. and M.M.; data curation, V.V. and O.L.; writing-original draft preparation, V.V., O.L. and M.M.; visualization, V.V. and O.L.; supervision, V.V. and M.M.; project administration, V.V. and M.M.; funding acquisition, V.V. and M.M. All authors have read and agreed to the published version of the manuscript.

Funding: The research was funded by the and by the Charles University project GAUK 1168820 “Hydrological extremes and their influence on surface water quality in headwaters of Czechia" and the Czech Science Foundation project 19-05011S "Spatial and temporal dynamics of hydrometeorological extremes in montane areas".

Conflicts of Interest: The authors declare no conflict of interest.

\section{References}

1. Valiya Veettil, A.; Mishra, A.K. Multiscale hydrological drought analysis: Role of climate, catchment and morphological variables and associated thresholds. J. Hydrol. 2020, 582. [CrossRef]

2. Cervi, F.; Blöschl, G.; Corsini, A.; Borgatti, L.; Montanari, A. Perennial springs provide information to predict low flows in mountain basins. Hydrol. Sci. J. 2017, 62, 2469-2481. [CrossRef]

3. Mishra, A.K.; Singh, V.P. A review of drought concepts. J. Hydrol. 2010, 391, 202-216. [CrossRef]

4. Raczyński, K.; Dyer, J. Multi-annual and seasonal variability of low-flow river conditions in southeastern Poland. Hydrol. Sci. J. 2020, 00, 1-16. [CrossRef] 
5. Deb, P.; Kiem, A.S.; Willgoose, G. Mechanisms influencing non-stationarity in rainfall-runoff relationships in southeast Australia. J. Hydrol. 2019, 571, 749-764. [CrossRef]

6. Van Loon, A.F. Hydrological drought explained. Wiley Interdiscip. Rev. Water 2015, 2, 359-392. [CrossRef]

7. Zhong, R.; He, Y.; Chen, X. Responses of the hydrological regime to variations in meteorological factors under climate change of the Tibetan plateau. Atmos. Res. 2018, 214, 296-310. [CrossRef]

8. Hänsel, S.; Ustrnul, Z.; Łupikasza, E.; Skalak, P. Assessing seasonal drought variations and trends over Central Europe. Adv. Water Resour. 2019, 127, 53-75. [CrossRef]

9. Mozny, M.; Trnka, M.; Vlach, V.; Vizina, A.; Potopova, V.; Zahradnicek, P.; Stepanek, P.; Hajkova, L.; Staponites, L.; Zalud, Z. Past (1971-2018) and future (2021-2100) pan evaporation rates in the Czech Republic. J. Hydrol. 2020, 590, 125390. [CrossRef]

10. Petek, M.; Kobold, M.; Šraj, M. Low-flow analysis of streamflows in Slovenia using R software and lfstat package. Acta Hydrotech. 2015, 27, 13-28.

11. Trnka, M.; Balek, J.; Štepánek, P.; Zahradnícek, P.; Možný, M.; Eitzinger, J.; Žalud, Z.; Formayer, H.; Turna, M.; Nejedlík, P.; et al. Drought trends over part of Central Europe between 1961 and 2014. Clim. Res. 2016, 70, 143-160. [CrossRef]

12. Langhammer, J.; Bernsteinová, J. Which Aspects of Hydrological Regime in Mid-Latitude Montane Basins Are Affected by Climate Change? Water 2020, 12, 2279. [CrossRef]

13. Hanel, M.; Vizina, A.; Máca, P.; Pavlásek, J. A multi-model assessment of climate change impact on hydrological regime in the Czech Republic. J. Hydrol. Hydromech. 2012, 60, 152-161. [CrossRef]

14. Hanel, M.; Rakovec, O.; Markonis, Y.; Máca, P.; Samaniego, L.; Kyselý, J.; Kumar, R. Revisiting the recent European droughts from a long-term perspective. Sci. Rep. 2018, 8, 1-11. [CrossRef]

15. Vicente-Serrano, S.M.; Gouveia, C.; Camarero, J.J.; Beguería, S.; Trigo, R.; López-Moreno, J.I.; Azorín-Molina, C.; Pasho, E.; Lorenzo-Lacruz, J.; Revuelto, J.; et al. Response of vegetation to drought time-scales across global land biomes. Proc. Natl. Acad. Sci. USA 2013. [CrossRef]

16. Orth, R.; Zscheischler, J.; Seneviratne, S.I. Record dry summer in 2015 challenges precipitation projections in Central Europe. Sci. Rep. 2016, 6, 1-8. [CrossRef]

17. Blöschl, G.; Hall, J.; Viglione, A.; Perdigão, R.A.P.; Parajka, J.; Merz, B.; Lun, D.; Arheimer, B.; Aronica, G.T.; Bilibashi, A.; et al. Changing climate both increases and decreases European river floods. Nature 2019, 573, 108-111. [CrossRef]

18. Jenicek, M.; Ledvinka, O. Importance of snowmelt contribution to seasonal runoff and summer low flows in Czechia. Hydrol. Earth Syst. Sci. Discuss. 2020, 1-23. [CrossRef]

19. Blahušiaková, A.; Matoušková, M.; Jeníček, M.; Ledvinka, O.; Kliment, Z.; Podolinská, J.; Snopková, Z. Snow and climate trends and their impact on seasonal runoff and hydrological drought types in selected mountain catchments in Central Europe. Hydrol. Sci. J. 2020, 00, 1-14. [CrossRef]

20. Laaha, G.; Gauster, T.; Tallaksen, L.M.; Vidal, J.-P.; Stahl, K.; Prudhomme, C.; Heudorfer, B.; Vlnas, R.; Ionita, M.; Van Lanen, H.A.J.; et al. The European 2015 drought from a hydrological perspective. Hydrol. Earth Syst. Sci. Discuss. 2016, 1-30. [CrossRef]

21. Ionita, M.; Tallaksen, L.M.; Kingston, D.G.; Stagge, J.H.; Laaha, G.; Van Lanen, H.A.J.; Scholz, P.; Chelcea, S.M.; Haslinger, K. The European 2015 drought from a climatological perspective. Hydrol. Earth Syst. Sci. 2017, 21, 1397-1419. [CrossRef]

22. Jehanzaib, M.; Shah, S.A.; Yoo, J.; Kim, T.W. Investigating the impacts of climate change and human activities on hydrological drought using non-stationary approaches. J. Hydrol. 2020, 588, 125052. [CrossRef]

23. Brázdil, R.; Trnka, M.; Mikšovský, J.; Řezníčková, L.; Dobrovolný, P. Spring-summer droughts in the Czech Land in 1805-2012 and their forcings. Int. J. Climatol. 2015, 35, 1405-1421. [CrossRef]

24. Forzieri, G.; Feyen, L.; Rojas, R.; Flörke, M.; Wimmer, F.; Bianchi, A. Ensemble projections of future streamflow droughts in Europe. Hydrol. Earth Syst. Sci. 2014, 18, 85-108. [CrossRef]

25. Brunner, M.I.; Tallaksen, L.M. Proneness of European Catchments to Multiyear Streamflow Droughts. Water Resour. Res. 2019, 55, 8881-8894. [CrossRef]

26. Stagge, J.H.; Kingston, D.G.; Tallaksen, L.M.; Hannah, D.M. Observed drought indices show increasing divergence across Europe. Sci. Rep. 2017, 7, 1-10. [CrossRef] [PubMed]

27. Jenicek, M.; Seibert, J.; Staudinger, M. Modeling of Future Changes in Seasonal Snowpack and Impacts on Summer Low Flows in Alpine Catchments. Water Resour. Res. 2018, 54, 538-556. [CrossRef] 
28. Bernsteinová, J.; Bässler, C.; Zimmermann, L.; Langhammer, J.; Beudert, B. Changes in runoff in two neighbouring catchments in the Bohemian Forest related to climate and land cover changes. J. Hydrol. Hydromech. 2015, 63, 342-352. [CrossRef]

29. Ledvinka, O. Evolution of low flows in Czechia revisited. Proc. Int. Assoc. Hydrol. Sci. 2015, 369, 87-95. [CrossRef]

30. Langhammer, J.; Su, Y.; Bernsteinová, J. Runoff response to climate warming and forest disturbance in a mid-mountain basin. Water 2015, 7, 3320-3342. [CrossRef]

31. Demirel, M.C.; Booij, M.J.; Hoekstra, A.Y. Impacts of climate change on the seasonality of low flows in 134 catchments in the River Rhine basin using an ensemble of bias-corrected regional climate simulations. Hydrol. Earth Syst. Sci. 2013, 17, 4241-4257. [CrossRef]

32. Stahl, K.; Hisdal, H.; Hannaford, J.; Tallaksen, L.M.; Van Lanen, H.A.J.; Sauquet, E.; Demuth, S.; Fendekova, M.; Jódar, J. Streamflow trends in Europe: Evidence from a dataset of near-natural catchments. Hydrol. Earth Syst. Sci. 2010, 14, 2367-2382. [CrossRef]

33. Kronenberg, R.; Franke, J.; Bernhofer, C.; Körner, P. Detection of potential areas of changing climatic conditions at a regional scale until 2100 for Saxony, Germany. Meteorol. Hydrol. Water Manag. 2015, 3, 17-26. [CrossRef]

34. Franke, J.; Goldberg, V.; Eichelmann, U.; Freydank, E.; Bernhofer, C. Statistical analysis of regional climate trends in Saxony, Germany. Clim. Res. 2004, 27, 145-150. [CrossRef]

35. Tolasz, R.; Míková, T.; Valeriánová, A.; Voženílek, V. Climate Atlas of Czechia, 1st ed.; Czech Hydrometeorological Institute, Palacký University Olomouc: Praha, Czech Republic, 2007; ISBN 978-80-86690-26-1.

36. Langhammer, J.; Hartvich, F.; Mattas, D.; Rödlová, S.; Zbořil, A. The variability of surface water quality indicators in relation to watercourse typology, Czech Republic. Environ. Monit. Assess. 2012, 184, 3983-3999. [CrossRef]

37. Czech Hydrometeorological Institute: Database of Surface Water Monitoring Network. Available online: http://portal.chmi.cz (accessed on 31 August 2020).

38. Gewässerkundlicher Dienst Bayern: Runoff Bavaria, Bayerisches Landesamt für Umwelt. Available online: https://www.gkd.bayern.de/en (accessed on 2 September 2020).

39. Sächsisches Landesamt für Umwelt, Landwirtschaft und Geologie: Hydrologische Daten. Available online: https://www.umwelt.sachsen.de/umwelt/infosysteme/lhwz/hydrologische-daten.html (accessed on 2 September 2020).

40. Osborn, D.R.; Harvey, A.C. Forecasting, Structural Time Series Models and the Kalman Filter. Economica 1991, 58. [CrossRef]

41. Golyandina, N.; Korobeynikov, A. Basic Singular Spectrum Analysis and forecasting with R. Comput. Stat. Data Anal. 2014, 71, 934-954. [CrossRef]

42. Hyndman, R.J.; Khandakar, Y. Automatic time series forecasting: The forecast package for R. J. Stat. Softw. 2008, 27. [CrossRef]

43. Laaha, G.; Blöschl, G. Seasonality indices for regionalizing low flows. Hydrol. Process. 2006, 20, 3851-3878. [CrossRef]

44. Koffler, D.; Gauster, T.; Laaha, G. lfstat: Calculation of Low Flow Statistics for Daily Stream Flow Data. R Package Version 0.9.4. Available online: https://cran.r-project.org/package=lfstat (accessed on 12 September 2020).

45. Young, A.R.; Round, C.E.; Gustard, A. Spatial and temporal variations in the occurrence of low flow events in the UK. Hydrol. Earth Syst. Sci. 2000, 4. [CrossRef]

46. R Core Team R: A Language and Environment for Statistical Computing. Available online: https://www.rproject.org/ (accessed on 1 August 2020).

47. Pohlert, T. trend: Non-Parametric Trend Tests and Change-Point Detection. R Package Version 1.1.4. Available online: https://cran.r-project.org/package=trend (accessed on 14 September 2020).

48. Gustard, A.; Demuth, S. Manual on Low-Flow Estimation and Prediction; World Meteorological Organisation: Geneva, Switzerland, 2008; Volume 50, ISBN 9789263110299.

49. Fleig, A.K.; Tallaksen, L.M.; Hisdal, H.; Demuth, S. A global evaluation of streamflow drought characteristics. Hydrol. Earth Syst. Sci. 2006, 10, 535-552. [CrossRef]

50. Tallaksen, L.M.; Madsen, H.; Clausen, B. On the definition and modelling of streamflow drought duration and deficit volume. Hydrol. Sci. J. 1997, 42, 15-33. [CrossRef] 
51. Hirsch, R.M.; Slack, J.R. A Nonparametric Trend Test for Seasonal Data With Serial Dependence. Water Resour. 1984, 20, 727-732. [CrossRef]

52. Libiseller, C.; Grimvall, A. Performance of partial Mann-Kendall tests for trend detection in the presence of covariates. Environmetrics 2002, 13, 71-84. [CrossRef]

53. Assani, A.A.; Landry, R.; Laurencelle, M. Comparison of interannual variability modes and trends of seasonal precipitation and streamflow in southern Quebec (Canada). River Res. Appl. 2012, 28, 1740-1752. [CrossRef]

54. Kliment, Z.; Matoušková, M.; Ledvinka, O.; Královec, V. Trend analysis of rainfall-runoff regimes in selected headwater areas of the Czech Republic. J. Hydrol. Hydromech. 2011, 59, 36-50. [CrossRef]

55. Spinoni, J.; Vogt, J.V.; Naumann, G.; Barbosa, P.; Dosio, A. Will drought events become more frequent and severe in Europe? Int. J. Climatol. 2018, 38, 1718-1736. [CrossRef]

56. Khaliq, M.N.; Ouarda, T.B.M.J.; Gachon, P.; Sushama, L. Temporal evolution of low-flow regimes in Canadian rivers. Water Resour. Res. 2008, 44,1-19. [CrossRef]

57. Hotovy, O.; Jenicek, M. The impact of changing subcanopy radiation on snowmelt in a disturbed coniferous forest. Hydrol. Process. 2020, 1-17. [CrossRef]

58. Kupková, L.; Potůčková, M.; Lhotáková, Z.; Albrechtová, J. Forest cover and disturbance changes, and their driving forces: A case study in the Ore Mountains, Czechia, heavily affected by anthropogenic acidic pollution in the second half of the 20th century. Environ. Res. Lett. 2018, 13. [CrossRef]

59. Robinson, M.; Cognard-Plancq, A.L.; Cosandey, C.; David, J.; Durand, P.; Führer, H.W.; Hall, R.; Hendriques, M.O.; Marc, V.; McCarthy, R.; et al. Studies of the impact of forests on peak flows and baseflows: A European perspective. For. Ecol. Manag. 2003, 186, 85-97. [CrossRef]

60. Sajikumar, N.; Remya, R.S. Impact of land cover and land use change on runoff characteristics. J. Environ. Manag. 2015, 161, 460-468. [CrossRef] [PubMed]

61. Prudhomme, C.; Giuntoli, I.; Robinson, E.L.; Clark, D.B.; Arnell, N.W.; Dankers, R.; Fekete, B.M.; Franssen, W.; Gerten, D.; Gosling, S.N.; et al. Hydrological droughts in the 21st century, hotspots and uncertainties from a global multimodel ensemble experiment. Proc. Natl. Acad. Sci. USA 2014, 111, 3262-3267. [CrossRef] [PubMed]

62. Alexander, L.V.; Tapper, N.; Zhang, X.; Fowler, H.J.; Tebaldi, C.; Lynch, A. Climate extremes: Progress and future directions. Int. J. Climatol. 2009, 29, 317-319. [CrossRef]

Publisher's Note: MDPI stays neutral with regard to jurisdictional claims in published maps and institutional affiliations.

(C) 2020 by the authors. Licensee MDPI, Basel, Switzerland. This article is an open access article distributed under the terms and conditions of the Creative Commons Attribution (CC BY) license (http://creativecommons.org/licenses/by/4.0/). 